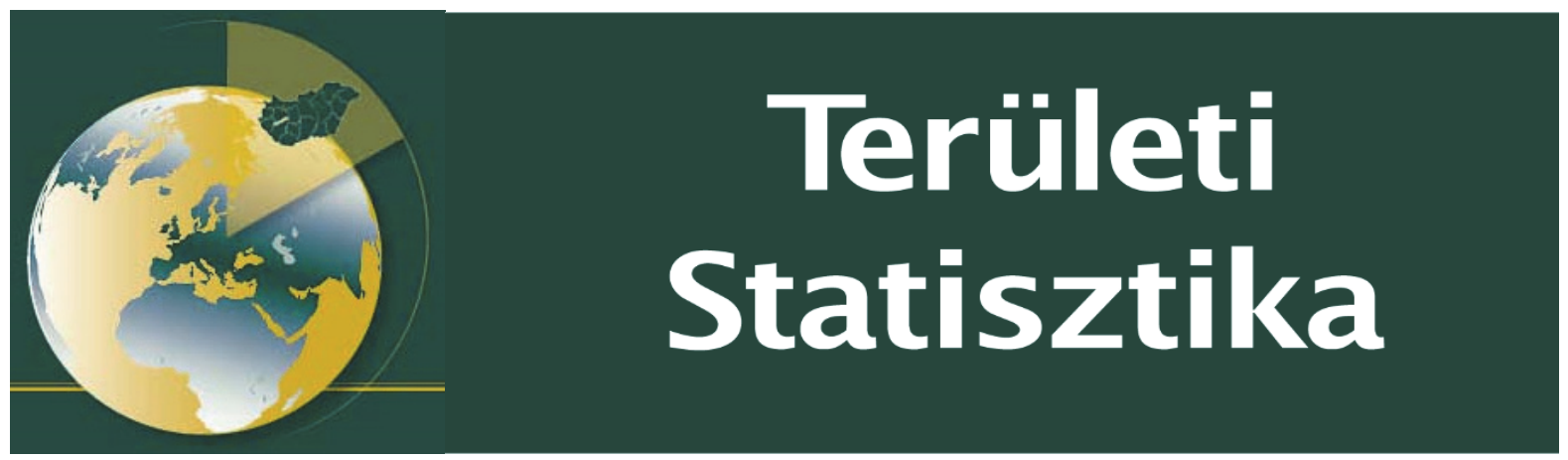

Közzététel: 2019. július 25.

A tanulmány címe:

Szerző:

A jövő fenntartható városai

Pomázi István, Budapesti Metropolitan Egyetem E-mail: pomazi.istvan@gmail.com

https://doi.org/10.15196/TS590405

Az alábbi feltételek érvényesek minden, a Központi Statisztikai Hivatal (a továbbiakban: KSH) Területi Statisztika c. folyóiratában (a továbbiakban: Folyóirat) megjelenó tanulmányra. Felhasználó a tanulmány, vagy annak részei felhasználásával egyidejüleg tudomásul veszi a jelen dokumentumban foglalt felhasználási feltételeket, és azokat magára nézve kötelezónek fogadja el. Tudomásul veszi, hogy a jelen feltételek megszegéséböl eredö valamennyi kárért felelösséggel tartozik.

1) A jogszabályi tartalom kivételével a tanulmányok a szerzői jogról szóló 1999. évi LXXVI. törvény (Szjt.) szerint szerzői műnek minősülnek. A szerzői jog jogosultja a KSH.

2) A KSH földrajzi és időbeli korlátozás nélküli, nem kizárólagos, nem átadható, térítésmentes felhasználási jogot biztosít a Felhasználó részére a tanulmány vonatkozásában.

3) A felhasználási jog keretében a Felhasználó jogosult a tanulmány:

a) oktatási és kutatási célú felhasználására (nyilvánosságra hozatalára és továbbítására a

4. pontban foglalt kivétellel) a Folyóirat és a szerző(k) feltüntetésével;

b) tartalmáról összefoglaló készítésére az írott és az elektronikus médiában a Folyóirat

és a szerző(k) feltüntetésével;

c) részletének idézésére - az átvevő mű jellege és célja által indokolt terjedelemben és az eredetihez híven - a forrás, valamint az ott megjelölt szerző $(\mathrm{k})$ megnevezésével.

4) A Felhasználó nem jogosult a tanulmány továbbértékesítésére, haszonszerzési célú felhasználására. Ez a korlátozás nem érinti a tanulmány felhasználásával előállított, de az Szjt. szerint önálló szerzői műnek minősülő mű ilyen célú felhasználását.

5) A tanulmány átdolgozása, újra publikálása tilos.

6) A 3. a)-c.) pontban foglaltak alapján a Folyóiratot és a szerző(ke)t az alábbiak szerint kell feltüntetni:

„Forrás: Területi Statisztika c. folyóirat 59. évfolyam 4. számában megjelent, Pomázi István által irt A jövö fenntartható városai c. tanulmány"

7) A Folyóiratban megjelenő tanulmányok kutatói véleményeket tükröznek, amelyek nem esnek szükségképpen egybe a KSH, vagy a szerzők által képviselt intézmények hivatalos álláspontjával. 


\title{
ISMERTETŐK
}

\section{A jövő fenntartható városai}

\author{
The Weight of Cities: Resource Requirements of Future \\ Urbanization (Swilling, M., Hajer, M., Baynes, T., Bergesen, J., Labbé, F., \\ Musango, J. K., Ramaswami, A., Robinson, B., Salat, S., Suh, S., Currie, P., \\ Fang, A., Hanson, A. Kruit, K., Reiner, M., Smit, S., Tabory, S.) \\ A Report by the International Resource Panel.
}

\section{Pomázi István}

Budapesti Metropolitan Egyetem

E-mail: pomazi.istvan@gmail.com

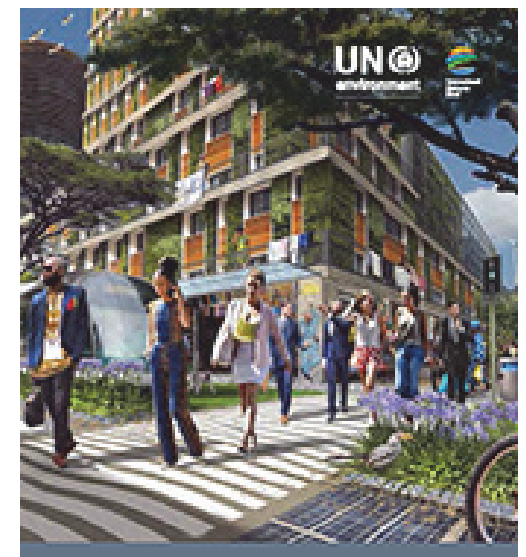

\section{THE WEIGHT OF CITIES \\ RESCURCERECUUREYUNTS}

United Nations Environment Programme, Nairobi, Kenya. 2018. 280 old.

A Nemzetközi Erőforrás Testületet (International Resource Panel - IRP) azért hozták létre, hogy független, koherens és hiteles tudományos értékelést nyújtson a természeti erőforrások felhasználásáról és azok környezeti hatásairól. A testület célul tűzte ki, hogy segítsen annak megértésében, miként választható el egymástól a gazdasági növekedés és a környezet állapotának romlása, a lakosság jóllétének emelkedését szem előtt tartva.

A testület titkárságát az ENSZ Környezetvédelmi Programja (United Nations Environment Programme - UNEP) múködteti Párizsban. Az IRP 2007. évi megalakulása óta 26 értékelést tett közzé. Az eddigi értékelések azt mutatták, hogy a kormányoknak, a vállalkozásoknak és tágabb értelemben a társadalomnak számos lehetôsége van arra, hogy olyan szakpolitikák végrehajtásán dolgozzanak együtt, amelyek - többek között összehangolt tervezés, technológiai innováció, stratégiai ösztönzők és beruházások révén végső soron fenntartható erőforrás-gazdálkodáshoz vezetnek.

Az IRP szakértői által készített 2018. évi jelentés arra a kérdésre keresi a választ, hogyan készülhetünk fel arra, hogy a városi lakosság lélekszáma 2015 és 2050 között várhatóan a kétszeresére növekszik?

A jelentés kvalitatív és kvantitatív módszerekre egyaránt támaszkodik. Az első ilyen jellegű jelentés három egymással összefüggő célkitűzéssel készült: (1) a jövőben

Területi Statisztika, 2019, 59(4): 453-456; DOI: 10.15196/TS590405 
várható városi növekedéshez szükséges erőforrások felmérése, (2) a fenntartható fejlesztési lehetőségek vizsgálata és (3) a kormányzás perspektívájának feltárása, azaz hogyan lehetséges az áttérés egy társadalmilag befogadó, erőforrás-hatékony és fenntartható városfejlesztésre.

Az 1. fejezet a következő évtizedek városi kihívásait veszi sorra. Az ENSZ demográfiai előrejelzése szerint a világon az urbanizáció szintje a 2015. évi 54-ről 2050-re 66\%-ra emelkedik, a városi lakosság létszáma 2,4 milliárd fővel növekedhet, melynek nagy részét Kína, India és Nigéria népességnövekedése teszi ki. A nyersanyagfogyasztás várhatóan gyorsabban növekszik, mint a városi lakosság lélekszáma. A városi anyagfelhasználás 2050-re megközelítőleg eléri a 90 milliárd tonnát. Az egyes városok fejlődése régiónként eltérő lesz, így ez a folyamat átalakítja a globális gazdaságot és az erőforrások iránti keresletet. A gazdasági növekedés és az erőforrás-kereslet nagy része majd a 10 millió főnél kisebb lélekszámú városokból származik.

A 2. fejezet a rendelkezésre álló adatok alapján 2050-ig előrejelzi a városi erőforrások felhasználásának várható növekedését. Az eddigi értékelésekben többnyire nemzeti szinten számított hazai anyagfelhasználás mutató (domestic material consumption - DMC) jól alkalmazható a városi szint (tonna/fó/év) esetében is.

A 3. fejezet azokat a beavatkozásokat azonosítja, amelyek egy méltányosabb térgazdaságon belül kulcsfontosságúak a nagyobb erőforrás-hatékonysághoz és társadalmi befogadáshoz. Ezek a beavatkozások magukban foglalják a városi morfológia térbeli szerkezetének átalakítását annak érdekében, hogy megfordítsák a városi terjeszkedés évszázados trendjét, így elősegítsék a kompakt városi növekedést, az élhető környezetet, az erőforrás-hatékony épületeket és városi rendszereket, valamint a viselkedési változásokat. Nyilvánvalóan ez az okos városokkal kapcsolatos megközelítéstől jelentôsen eltér, az ugyanis a magántulajdonban lévő gépjármúparkon alapul, továbbá a földhasználat, a földjogok és a zónák politikai eszközeinek alkalmazása a közepes és a magas jövedelmú tulajdonosoknak kedvez. A városi morfológiai beavatkozások elsődleges jelentősége abban áll, hogy azok összességben az integrált tervezésre képes önkormányzatok által irányíthatók. A szerzők szerint jól megtervezett beavatkozásokkal a városi termelékenység akár a 10-szeresére is emelhetô. A bölcs várostervezésben rejlik a legnagyobb potenciális megtakarítás, nulla vagy negatív költség mellett. A sưrúbb beépítésû, szorosan összekapcsolódó városok sokkal hatékonyabban tudnak gazdálkodni a rendelkezésre álló természeti erőforrásokkal, mint a jelenlegi (szétterülő és szétaprózott) városrendszerek. A városi rendszerek termelékenységének 10-szeresére emelkedése oly módon tenné lehetôvé a városok további gazdasági növekedését és a szegénység felszámolását, hogy közben a környezeti terhelés a felére csökkenhetne.

Az eddigi vizsgálatok azt bizonyítják, hogy a nagyobb sưrűségú és kompakt városi formák a felére vagy annál nagyobb mértékben visszaszoríthatják az üvegházhatású gázok kibocsátását, az energiahatékony épületek hasonló mértékben csökkenthetik az 
energiaigényt, a hatékony energiarendszerekkel további 20\%-os megtakarítást érhetnek el, valamint a viselkedésbeli változások szintén jelentősen csökkenthetik az energiaigényt. Ezek összességében a városi energiafelhasználás 10-szeres csökkentését eredményezhetik.

A 4. fejezet integrált életciklus-elemzési (Life Cycle Assessment - LCA) keretrendszert alkalmaz annak értékelésére, hogy az erőforrás-felhasználás szempontjából a korábbinál hatékonyabb technológiák bevezetése hogyan befolyásolhatja a városi környezet állapotát és a természeti erőforrások használatát. A szerzők az általuk vizsgált 84 városról és a szakirodalomból rendelkezésre álló empirikus adatok felhasználásával 2050-ig jelezték előre a személygépkocsi-közlekedés, a kereskedelmi épületek és a fütési-hưtési energia iránti igényt. A jelenlegi trendeket előrevetítő forgatókönyvet hasonlították össze egy erőforrás-hatékony forgatókönyvvel. Utóbbiban azt feltételezték, hogy egyre inkább elterjednek az erőforrás-hatékony technológiák (például a gyorsbuszok rendszere, a zöld tanúsítvánnyal rendelkező kereskedelmi épületek, a távfütési rendszerek és az alacsony szén-dioxid-kibocsátású villamosenergia-ellátás), amelyek összhangban vannak a Párizsi Klíma Egyezményben elfogadott $2^{\circ} \mathrm{C}$-os globális felmelegedési küszöbértékkel.

Az 5. fejezet azt veszi górcső alá, hogyan segítheti az infrastrukturális projektek integrált tervezése a városokat erőforrásaik hatékonyabb felhasználásában. A jelentés három ország öt nagyvárosának - Minneapolis (Egyesült Államok), Peking és Kaifeng (Kína), Ahmedábád és Delhi (India) - példáján keresztül ismerteti ennek megvalósíthatóságát.

Minneapolis esettanulmánya szerint jelentős erőforrás-hatékonyság érhető el, ha a következő beavatkozások kombinációját hajtiák végre: energiahatékony épületek tervezése, az összes energiafelhasználás 65\%-ának nem fosszilis tüzelőanyagokból (beleértve a nukleáris és a megújuló energiaforrásokat) történő előállitása, a tömegközlekedési szolgáltatások bővítése, negyedik generációs távfűtési rendszerek kiépítése, a cementalapú építési rendszerek helyettesítése korszerű, faépítési megoldásokkal. Ennek eredményeként 2050-re az üvegházhatású gázok kibocsátása 33, az építőipari nyersanyagok felhasználása 62 , valamint a fútési és hútési energia iránti igény $40 \%$-kal mérsékelhető.

Peking és Kaifeng esetében a gyors népességnövekedés következményeivel összefüggésben jelentős erőforrás-hatékonyság érhető el egy körülbelül ötéves időszakon belül, ha a következő szakpolitikailag megalapozott beavatkozásokat összehangoltan hajtják végre: az ipari termelés hatékonyságának javítása a „Top 10000 Program” (a kínai kormány által támogatott energiahatékonysági program) figyelembevételével, a negyedik generációs távfütési rendszerek fejlesztése, ipari hulladékhő újrahasznosítása, energiahatékony épületek tervezése, kombinált hő- és villamosenergia-elóállitás, energetikaihulladék-égetés, továbbá az építőanyagok cementtartalmának kiváltása pernyével és salakkal. Az eredmények azt mutatják, hogy négy év alatt jelentős anyagmegtakarítás és az üvegházhatásúgáz-kibocsátás 40\%-os csökkentése érhető el.

Területi Statisztika, 2019, 59(4): 453-456; DOI: 10.15196/TS590405 
Az Ahmedábád és a Delhi esettanulmánya a nyomornegyedek rehabilitációjára - a belvárosban többszintes épületek építésére - összpontosít. Bebizonyosodott, hogy (az egyszinteshez képest) ez 36\%-kal csökkentheti az anyaghasználatot, miközben kisebb motorizált utazási igénnyel jár és javítja a foglalkoztatáshoz való hozzáférést, amely viszont növeli a népsűrűséget. A szerzők azt is kiszámították, hogy Delhi lakossága szegényebb 50\%-ának a jelenlegit meghaladó villamosenergia-fogyasztása 13\%-kal növelné az összes energiaigényt.

Az esettanulmányok megerősítik azt a következtetést, hogy az összehangolt, ágazatok közötti beavatkozások révén történő erőforrás-megosztás a kulcsfontosságú infrastrukturális ágazatokban hozzájárulhat az erőforrás-felhasználás 30-50\%-os csökkenéséhez.

A 6. fejezet arra a kérdésre keresi a választ, hogy milyen irányításra és tervezésre van szükségük a városoknak erőforrás-gazdálkodásuk javítása érdekében?

A városi átmenet kihívásainak megfelelóen egyensúlyt kell teremteni az információs fejlesztés, az emberi fejlődés és a fenntartható fejlesztés között. Ebből a célból szükség lesz a városi fejlesztések vállalkozói szemléletú irányítására, amely maximalizálja az új információs és kommunikációs technológiákban rejló lehetőségeket, de nem az okos városok paradigmáján belül. Ahhoz, hogy a városok és a települések gazdaságilag befogadók, továbbá erőforrás-hatékonyak legyenek, olyan paradigmaváltásra van szükség, amely nemcsak kivételezett társadalmi csoportok, hanem valamenynyi polgár érdekeit szolgálja. E paradigmaváltás nélkül az információs, az emberi és a fenntartható fejlődés nem hozható egyensúlyba.

A jelentés utolsó fejezete egyértelmúen rávilágít arra, hogy új urbanizációs stratégiára van szükség, amelynek középpontjában az erőforrás-hatékonyság és a társadalmi befogadás áll. A várostervezésben és -fejlesztésben érdekelt feleknek - beleértve a tudományos kutatókat, a várospolitikusokat és -tervezőket, valamint az üzleti élet szereplőit - újra kell gondolniuk a városok és a természeti környezet kapcsolatrendszerét. Ehhez előremutató és megfontolandó szakpolitikai ajánlásokat tettek a kötet szerzői. 